\title{
DIGITAL PAYMENTS: A STUDY ON POST DEMONETIZATION PERIOD
}

\section{Dr. JOJOMON N A}

Associate Professor of Commerce, PM Government College, Potta, Chalakudy, Kerala, India

\begin{abstract}
Digital payment is the way in which payments are made through different digital methods. The unforeseen move and the non- availability of cash acted as a catalyst and has forced the people to use more digital mode for making transactions. This created an increase in digital payments. The various initiatives by the Government in promoting digital payments like reduction in taxes and incentives helped a lot in including many people who were unaware of and unwilling to use digital mode, into the main stream of digital payment. The different digital payment methods are cards, Bharat Interface for Money, Aadhar enabled payment system, Unified payment interface, internet banking, mobile banking, e-wallet, Point of sale etc. The present study analyses the change in the method of payment after demonetization in Thiruvananthapuram district.
\end{abstract}

KEYWORDS: Digital Payment, Demonetization, Change, Usage, Reasons, Problems

Received: Feb 09 2017; Accepted: Apr 03, 2017; Published: Apr 06, 2017; Paper Id.: IJECRAPR20175

\section{INTRODUCTION}

Digital payment is the way in which payments are made through different digital methods. The parties involved in the digital payments uses digital methods to send and receive money. No cash in involved in digital payments. On November 8, 2016, the Government of India has announced the demonetization by withdrawing500 rupee notes and1000 rupee notes which constituted 86 percent of the notes in circulation. One of the aims of the move was to achieve a cashless economy. The unforeseen move and the non- availability of cash acted as a catalyst and has forced the people to use more digital mode for making transactions. This created an increase in digital payments. India is a cash centric economy and transformation to a cashless economy is a difficult task. The households have a mindset which did not change frequently. They will prefer the method of payment which they consider safe and convenient. The various initiatives by the Government in promoting digital payments like reduction in taxes and incentives helped a lot in including many people who were unaware of and unwilling to use digital mode into the main stream of digital payment. This increasing trend is continuing in post demonetization period also. The different digital payment methods are cards, Bharat Interface for Money, Aadhar enabled payment system, Unified payment interface, internet banking, mobile banking, e-wallet, Point of sale etc. Digital payments will bring transparency and accountability in the transactions and helps to achieve financialinclusion.

Banking cards provide more convenience, security and control over finance than any other payment method to the customers. The banking cards include debit card, credit card and prepaid cards. The unstructured supplementary service data enables the customer to use mobile banking transactions using basic feature mobile phone and another advantage is that the customer need not have an internet facility in the mobile phone. Unified payment interface is a payment system that enables multiple bank accounts to single mobile application which is developed by National Payments Corporation of India which helps to include several banking features. An e- wallet 
is a method of digital payment in which cash can be carried in digital format. For using an e-wallet, a customer's account is required to be linked to the e- wallet to deposit money. To make purchase, an individual can use smart phone instead of physical plastic cards. Internet banking is an electronic payment system that enables the customers to conduct financial transactions electronically through bank's or other institution's website. Mobile banking is an electronic payment system which allows the customers to conduct financial transactions using mobile phone. Aadhar enabled payment system is a method of digital payment which is developed by National payment corporation of India to encourage cashless transaction which is based on Unique Identification number that allows to make various financial transactions like transfer of funds, cash withdrawal, deposit of cash etc. Point of Sale is the place where retail transaction is completed. It is the point where the customer makes payment to the owner of the shop or merchant in exchange of goods andservices.

\section{OBJECTIVES OF THE STUDY}

The broad objective of the study is to find the change in the method of payment after demonetization. The specific objectives of the study include:

- To find the change in different payment methods between urban and rural households after demonetization.

- To analyse the usage of different methods of digitalpayment.

- To study the reasons for using different digital paymentmethods.

- To study the problems faced by households in using different digital paymentmethods.

\section{REVIEW OF LITERATURE}

- Piyush\&Dhani (2017) in their study demonetization and its impact on adoption of digital payment: opportunities and challenges has brought out the fact that the digital payment had given relief and force to learn digital transactions after demonetization. People adopted technology slowly, but don't wanted to pay extra for digital transactions. However people of India face many problems during demonetization and they suffered with no cash.

- Sumit (2018) in his study India's demonetization drive:- a necessary jolt towards a more digital economy suggest that the impact of demonetization on digital payment adoption is most muted in regions that are underdeveloped economically, which lag behind in financial inclusion and the development of technology infrastructure. Demographic factors has also contribute to the adoption of digital technology and found the effect was lower in areas with more consumers that are older, married female and under educated and therefore need to be more conservative.

- Chhavi John (2018) in the study a study on digital payments in India with perspective of consumer's adoption has commented that the effect of adopting digital payments impact on consumers of the banking sector of India. The results indicate that the development of technology for digital payments have improved the performance of banking sector and abled to achieve the motive cash less country. Banks should take effective measures in creating awareness towards the effective usage of technology and security.

- Pratik Bhakta (2018) have brought out the fact in his study demonetization impact: bharatgoing digital forpaymentsthatmoreIndiansfromsmallertownsandcitieswerepayingdigitallyforgoodsand services, raising expectations of sustained growth for non- cash payments, even as Reserve bank of India indicated the sharp spike 
in digital transactions following the 2016 note ban has evened out in recent years. Payments company executives estimate that card transactions in towns with population of up to one million has doubled in two years since demonetization.

- Suma\&Hema (2018) in their study a study on digital payments in India with perspective of consumer's adoption examines the effect of adopting digital payments impact on consumers of the banking sector in India. The results indicates that the development of technology for digital payments have improved the performance of banking sector and abled to achieve the motive cashless country. Banks should take effective measures in creating awareness towards the effective usage of technology andsecurity.

\section{RESEARCH METHODOLOGY}

On the basis of the objectives formulated, the following methodology is used for conducting the study.

\section{METHOD ADOPTED}

The present study is an attempt to identify the change in the mode of payment after demonetization in Thiruvananthapuram district. As such, the present study is descriptive and analytical in nature,

For the present study, both primary data and secondary date are used. Primary data is collected from urban and rural households in Thrissur district. Besides primary data, secondary data is collected from various articles, journals, published and unpublished reports and websites.

\section{Sample for the study}

In the present study, thepopulation constitutes households in urban and rural area. Judgment sampling is used for selecting the sample for the study. The sample size is 100 , where 50 households from urban area and 50 households from rural area. The criteria area is selected on the basis of the judgment.

\section{Variables Identified}

- Change in the method ofpayment

- Reasons for using digital paymentmethods

- Problems in using digital paymentmethods

\section{Tools for Analysis}

The primary data collected from the households are tabulated, analysed and interpreted using the statistical package SPSS by using the tools like percentage, Mann whitney U test Friedman Test, and Multiple Response Test.

\section{Analysis and Interpretations}

\section{OBJECTIVE 1}

\section{Change in Method of Payment on the Basis of area}

In India, most of the transactions were carried out using cash. The demonetization move by the government created a cash scarcity which insisted the people to use digital mode for the transactions. In this situation, it is relevant to find whether the move has helped in achieving a cashless economy and whether there is any difference in the method of payment among urban and ruralhouseholds. 
Methods of Payments used by urban and Rural Households during

Pre- demonetization period Figure1

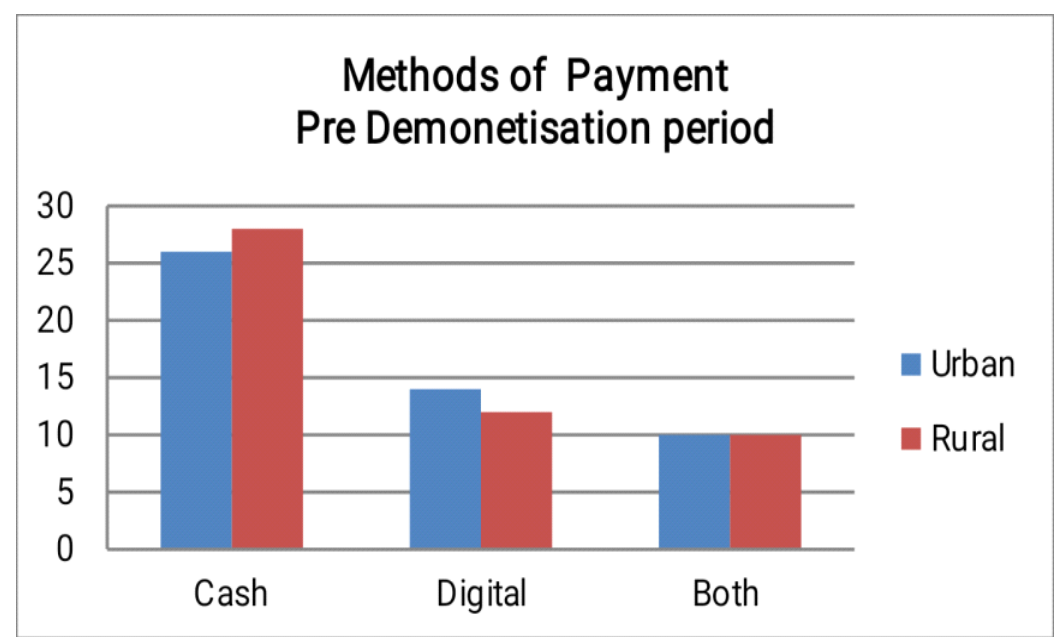

Methods of Payments used by urban and Rural Households during

Post demonetization Period Figure 2

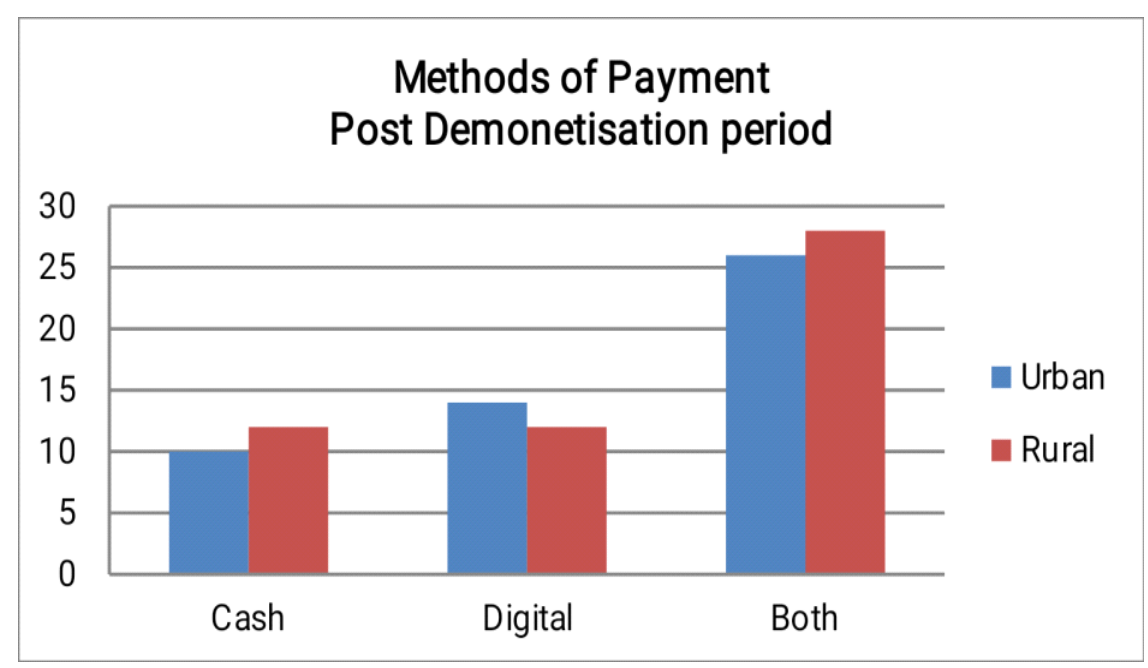

Figure 1 and 2 depicts the methods of payments used by urban and rural households during pre and post demonetization period respectively. During pre- demonetization period cash was the king. Households in both urban and rural area have used cash for majority of the transactions. The use of digital payment is comparatively high in urban area. But during post demonetization period, most of the urban and rural households are using both cash and digital as their method of payment. Like in the pre demonetization period, more households in urban area are fully using digital payment methods for their transactions. Demonetization move has forced the households to use cashless methods, but as soon as cash became available in the economy they have started to use cash along with digital payment methods. The use of both cash and digital for payments shows that cash will be always a part of conduct and this cannot be changedeasily.

Table 1: Change in the Methods of Payment of Households on the Basis of Area

\begin{tabular}{|l|c|}
\hline Area & Mean ranks \\
\hline Rural & 54.00 \\
\hline Urban & 47.00 \\
\hline
\end{tabular}

Source: Primary data 
Table 2: Test Statistics showing Change in Methods of Payment of Households on the Basis of Area

\begin{tabular}{|l|c|}
\hline Mann-Whitney U & $\mathbf{1 0 7 5 . 0 0 0}$ \\
\hline Z & -1.655 \\
\hline Sig & 0.098 \\
\hline
\end{tabular}

Source: Computed data

In order to find out whether there is any difference in the method of payment among urban and rural households, Mann Whitney $U$ test is used. The mean rank of urban area is 47 and that of rural area is 54 . As per the test, $\mathrm{Z}$ value is 1.655 and level of significance is greater than 5 percent.

As the significance value is greater than 5 percent, there is no significant difference in the mean ranks of urban and rural households for the change in methods of payments.

\section{OBJECTIVE 2}

\section{Usage of Different Digital Payment Methods}

Instead of using cash, paying for goods and services electronically is known as digital payment. In order to promote cashless transactions whole over the country, the government is introducing various initiatives. According to the use and convenience, households select the different digital payment methods. The different methods of digital payment are cards, Bharat interface for money, Unified payment interface, Internet banking, mobile banking, e- wallet, Point of sale, Unstructured supplementary service data, Aadhar enabled payment system etc. The present study analyses the usage of various digital payment methods such as debit card, credit card, unified payment interface, internet banking, mobile banking and e-wallet among urban and rural households.

Table 3: Usage of Different Digital Payment Methods

\begin{tabular}{|l|c|l|l|l|}
\hline \multirow{2}{*}{ Digital Payment Method } & \multicolumn{2}{|c|}{ Urban Area } & \multicolumn{3}{|c|}{ Rural Area } \\
\cline { 2 - 5 } & No & Percent & No & Percent \\
\hline Debit card & 40 & & 40 & \\
\hline Credit card & 30 & & 15 & \\
\hline UPI & 32 & & 26 & \\
\hline E-wallet & 40 & & 22 & \\
\hline Internet banking & 32 & & 24 & \\
\hline Mobile banking & 22 & & 18 & \\
\hline
\end{tabular}

Source: Primary data

Table 3 shows the usage of different digital payment methods among urban and rural households. The most commonly used digital payment method by both urban and rural households are debit cards. The reason for this might be because of the convenience and the advantage of not increasing the credit score. And also debit card can be used at ATMs and point of sale. In urban area, e-wallet is also preferred by the households as it reduces the chance of frauds and makes the payment secured. Unified payment interface is the second preferred method of digital payment by both rural and urban area. The least preferred method of digital payment in rural area is credit card might because of perception of the households considering credit card as risky and rise in credit score.

\section{OBJECTIVE 3}

\section{Reasons for using Different Digital Payment Methods}

In earlier days, most of the people are unaware of and unwilling to use the digital method for making the payments. But as a result of the demonetization, the government has become able to include many people into the main stream of different 
digital payment methods. If the households find it easy, safe and convenient to use the digital method, they will continue to use the same. The identified reasons are non- cash availability, convenience, security, transparency, accountability, financial gains and cost savings.

Table 4: Reasons for using Different Digital Payment Methods

\begin{tabular}{|l|c|c|c|}
\hline \multirow{2}{*}{\multicolumn{1}{|c|}{ Reasons }} & \multicolumn{2}{c|}{ Responses } & \multirow{2}{*}{ Percent of CASES } \\
\cline { 2 - 3 } & $\mathbf{N}$ & Percent & \\
\hline Non cash availability & 38 & $9.7 \%$ & $38.0 \%$ \\
\hline Convenience & 72 & $18.5 \%$ & $72.0 \%$ \\
\hline Security & 40 & $10.3 \%$ & $40.0 \%$ \\
\hline Transparency & 62 & $15.9 \%$ & $62.0 \%$ \\
\hline Accountability & 56 & $14.4 \%$ & $56.0 \%$ \\
\hline Financial gains & 68 & $17.4 \%$ & $68.0 \%$ \\
\hline Cost savings & 54 & $13.8 \%$ & $54.0 \%$ \\
\hline
\end{tabular}

Source: Primary data

From the analyze, it is found that convenience (18.5 percent) is considered as the reason for using different digital payment methods out of which 72 percent is using only because of this reason. For popularizing the digital payments, the government and other issuers are providing different schemes and discounts to the people. So, financial gains provided by the digital payments are also considered as a reason for using digital payment method followed by transparency and accountability. The cash shortage is not considered as a main reason for using digital payment methods.

\section{OBJECTIVE 4}

\section{Problems Faced by Households in using Different Digital Payment Methods}

Even though there are different methods of digital payments, there are certain issues which create hesitation in the minds of the people from using digital payments. The identified reasons are security issues, no adequate infrastructure, lack of operational knowledge, loos of finance control, chance of fraudulent activities and lack of familiarity of technology. The Friedman test is used to analyze the problems faced by households in using different digital payment methods.

Table 5: Problems Faced by Households in using Different Digital Payment Methods

\begin{tabular}{|l|c|}
\hline \multicolumn{1}{|c|}{ Problems } & Mean Rank \\
\hline Security problems & 1.69 \\
\hline No adequate infrastructure & 4.14 \\
\hline Lack of operational knowledge & 4.34 \\
\hline Loss of finance control & 4.41 \\
\hline Chance of fraudulent activities & 2.22 \\
\hline Lack of familiarity of technology & 4.20 \\
\hline
\end{tabular}

Source: Primary Data

Table 5 shows the problems faced by households in using different digital payment methods. Security issues are considered as the main problem in using digital payment methods. The stealing of personal information, hacking of accounts, withdrawal of money from accounts all have created fear in the mind of the households in using digital payment. Another problem is chance of fraudulent activities followed by lack of adequate infrastructure and lack of familiarity of technology. The lowest rank is given to loss of finance control. 
Table 6: Friedman Test showing Problems Faced by Households in Using Different Digital Payment Methods

\begin{tabular}{|l|c|}
\hline Chi square & 210.057 \\
\hline Df & 5 \\
\hline Sig. & 0.000 \\
\hline
\end{tabular}

Source: Computed data

Table 6 depicts that there is significant difference in the problems faced by households in using different digital payment methods as the level of significance is less than 5 percent.

\section{FINDINGS}

The major findings of the study include:

- During pre- demonetization period, cash is mainly used for making transactions by majority of the urban and rural households and digital payment methods are mostly used by urbanhouseholds.

- Use of cash has reduced and more households have shifted to digital payment methods during post demonetizationperiod.

- Majority of the households are using both cash and digital methods for making payments during post demonetizationperiod.

- There is no significant difference in the mean ranks of urban and rural households for the change in methods ofpayments.

- The most commonly used digital payment method by both urban and rural households are debitcards.

- The least preferred method of digital payment in rural area is creditcard.

- Convenience is considered as the reason for using different digital paymentmethods.

- The cash shortage is not considered as a main reason for using digital paymentmethods.

- Security issues are considered as the main problem in using digital paymentmethods.

- There is significant difference in the problems faced by households in using different digital payment methods

\section{CONCLUSIONS}

Households in the economy are switching over to different methods of digital payments after demonetization. Adoption of Unified payment interface has boosted the digital payments. Even though the digital payments are increasing, our economy cannot completely achieve cashless economy easily. Both cash and digital payment methods are using after demonetization period. Debit card and unified payment interface are the most commonly used digital payment method. Households considered convenience as the reason for using digital payment methods. Security is the main concern of the households in using digital payment methods.

\section{REFERENCES}

1. Piyushkumar., Dr Dhani Shankar Chaubey . (2017). Demonetization and its impact on adoption of digital payments: opportunities, issues and challenges. Abhinav National Monthly Referred Journal of Research in commerce and Management, $6(6)$ 
2. SumitAgarwal. (2018). India's demonetization drive:- A necessary jolt towards a more digital economy . Retrieved from https://www.forbes.com/sites/nusbusinessschool/2018/09/01/indias-HYPERLINK

"https://www.forbes.com/sites/nusbusinessschool/2018/09/01/indias-demonetization-drive-a-necessary-jolt-towards-a-moredigital-economy" demonetization-drive-a-necessary-jolt-towards-a-more-digital-economy.

3. Chhavi John. (2018). Digital payments and demonetization. International Journal of Research and Analytical Review, 5(1),118-122

4. Pratik Bhakta. (2018). Demonetization impact: Bharat going digital for payments. Retrieved from https://economictimes.indiatimes.com/industry/banking/finance/banking/demonetisation-impact-HYPERLINK

"https://economictimes.indiatimes.com/industry/banking/finance/banking/demonetisation-impact-bharat-going-digital-forpayments/articleshow/66550675.cms?from=mdr" bharat-going-digital-for-payments/articleshow/66550675.cms?from=mdr

5. Suma Vally, K., \&HemaDivya,K. (2018). A study on digital payments in India with perspective of consumer's adoption. International journal of pure and applied mathematics, 119(15),1259-1267.

6. http://cashlessindia.gov.in/digital payment methods.html 